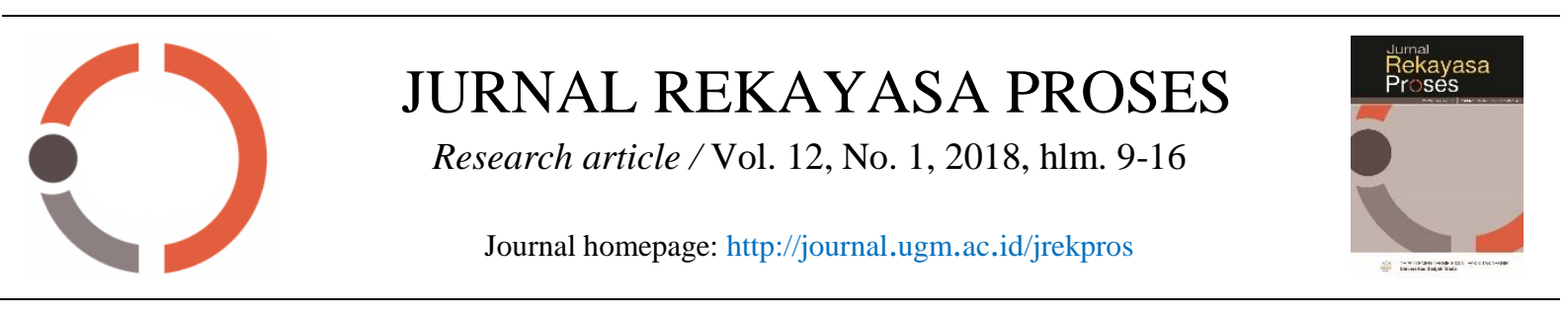

\title{
Model Dispersi Gas dan Vapor Cloud Explosion pada Kebocoran Outlet Pigtail Tubes Primary Reformer
}

\author{
Perwitasari", P. Sumardi, dan Indra Perdana \\ Departemen Teknik Kimia, Fakultas Teknik, Universitas Gadjah Mada \\ Jl Grafika No. 2 Kampus UGM, Yogyakarta, 55281 \\ *Email: perwita08@gmail.com
}

(Submisi: 9 Maret 2018; Revisi: 21 April 2018; Penerimaan: 23 April 2018)

\begin{abstract}
A B S T RACT
Outlet pigtail tubes, one of the components in primary reformer, have a function to carry the reformed gas from the catalyst tubes to the collection manifold. Moreover, it also has a function to provide the required flexibility within the system to avoid overstress at the end of connections of the pigtail to the manifold and to the bottom of the catalyst tube. It operates in an extreme condition with temperature range of $825-850^{\circ} \mathrm{C}$ and pressure $36.2 \mathrm{~kg} / \mathrm{cm}^{2}$ which is possible to initiate a failure. The consequences of outlet pigtail tubes failure are a dispersion of synthesis gas and vapor cloud explosion. This research aimed to make a model of those consequences with an assumption that the leakage hole was the same as the diameter of outlet pigtail tubes. The gas dispersion model used in this research was dense gas dispersion continuous release model. The results showed that the highest ratio of synthesis gas-air concentration was 0.1 at $17.4 \mathrm{~m}$ distance from leaking point. Whereas the lowest ratio of synthesis gas-air concentration was 0.002 at $163.4 \mathrm{~m}$ distance from leaking point. The highest ratio of the concentration of gas dispersion gave vapor cloud explosion energy of about $11.67 \times 10^{5} \mathrm{~kJ}$ with an overpressure of about $8.41 \mathrm{kPa}$. The overpressure caused a partial demolition of the building (for example control room), panels blow in, and fastening fails of equipment or machines around the area.
\end{abstract}

Keywords: outlet pigtail tubes, gas dispersion, vapor cloud explosion

\section{A B S T R A K}

Outlet pigtail tubes adalah salah satu komponen pada primary reformer yang berfungsi untuk membawa gas hasil reforming dari tube katalis ke manifold. Selain itu outlet pigtail tubes juga berfungsi untuk memberikan fleksibilitas yang diperlukan di dalam sistem sehingga terhindar dari overstress di bagian akhir sambungan antara pigtail dengan manifold dan bagian bawah dari tube katalis. Outlet pigtail tubes beroperasi pada kondisi ekstrim yaitu suhu $825-850{ }^{\circ} \mathrm{C}$ dan tekanan 36,2 $\mathrm{kg} / \mathrm{cm}^{2}$ yang mana memungkinkan untuk terjadinya kegagalan. Konsekuensi dari kegagalan outlet pigtail tubes adalah dispersi gas sintesis dan ledakan awan uap. Penelitian ini bertujuan untuk membuat model dari konsekuensi tersebut dengan asumsi bahwa lubang kebocoran sama dengan diameter outlet pigtail tubes. Model dispersi gas yang digunakan dalam penelitian ini adalah model dispersi dense gas untuk pengeluaran yang kontinu. Hasil menunjukkan bahwa rasio konsentrasi gas sintesis-udara tertinggi adalah 0,1 pada jarak 17,4 meter, sedangkan rasio konsentrasi terendah adalah 0,002 pada jarak 163,4 meter. Konsentrasi tertinggi dari gas terdispersi memberikan energi untuk ledakan awan uap sebesar 11,67 x $10^{5} \mathrm{~kJ}$ dengan overpressure sebesar 8,41 kPa. Overpressure tersebut menyebabkan kerusakan pada sebagian dari bangunan (sebagai contoh ruang kontrol), terlemparnya papan, dan mempercepat kegagalan dari peralatan atau mesin di sekitar area. 


\section{Pendahuluan}

Primary reformer merupakan salah satu alat proses yang vital pada industri pupuk yang berfungsi untuk mengubah gas alam menjadi sintesis gas $\left(\mathrm{H}_{2}, \mathrm{CO}\right.$ dan $\left.\mathrm{CO}_{2}\right)$ melalui reaksi steam methane reforming (SMR). Gas alam masuk ke dalam primary reformer pada suhu 480-500 ${ }^{\circ} \mathrm{C}$ dan tekanan $39,2 \mathrm{~kg} / \mathrm{cm}^{2}$, kemudian keluar pada suhu $800-850{ }^{\circ} \mathrm{C}$ dan tekanan 36,2 $\mathrm{kg} / \mathrm{cm}^{2} \quad$ (Kusumaningtyas, 2010). Primary reformer terdiri dari dua bagian yaitu radiant section dan convection section. Radiant section terdiri dari kumpulan tube katalis dan di dalam tube tersebut terjadi reaksi steam methane reforming. Bagian bawah tube katalis terhubung dengan outlet pigtail tubes yang berfungsi untuk membawa gas hasil reforming dari tube katalis ke manifold. Selain itu outlet pigtail tubes juga berfungsi untuk memberikan fleksibilitas yang diperlukan di dalam sistem sehingga terhindar dari overstress di bagian akhir sambungan antara pigtail dengan manifold dan bagian bawah tube katalis (Barnett dan Price, 2013). Oleh karena beban suhu dan tekanan yang harus ditahan cukup tinggi, maka dimungkinkan untuk terjadinya kegagalan pada outlet pigtail tubes. Salah satu kegagalan yang mungkin terjadi adalah adanya kebocoran pada outlet pigtail tubes yang disebabkan karena liquid metal embrittlement. Liquid metal embrittlement terjadi karena adanya reaksi antara aluminium foil yang digunakan sebagai isolasi pada outlet pigtail tubes dengan chromium oxide yang merupakan salah satu bahan campuran (alloy) penyusun outlet pigtail tubes pada suhu $850{ }^{\circ} \mathrm{C}$ (Pandey dkk., 2017). Reaksi yang terjadi ditunjukkan pada Persamaan 1:

$$
\mathrm{Cr}_{2} \mathrm{O}_{3}+2 \mathrm{Al} \rightarrow 2 \mathrm{Cr}+\mathrm{Al}_{2} \mathrm{O}_{3}
$$

Reaksi tersebut bersifat sangat eksotermis sehingga dapat menimbulkan pemanasan lokal pada permukaan outlet pigtail tubes dan menyebabkan terbentuknya molten metal corrosion (Pandey dkk., 2017). Proses korosi yang terjadi dapat menyebabkan timbulnya kebocoran pada outlet pigtail tubes.

Beberapa kegagalan yang pernah terjadi pada pigtail tubes reformer antara lain terjadi intergranular stress oxidation cracking pada outlet pigtail tubes steam reformer furnace setelah beroperasi selama 60.000 jam. Hal ini disebabkan oleh okidasi pada suhu tinggi yang terjadi berulang-ulang (Kodali dan Richert, 2003). Selain itu juga terjadinya creep pada bagian luar outlet pigtail tubes yang berujung pada keretakan setelah beroperasi selama 3 tahun. Terjadinya creep disebabkan oleh degradasi metal microstructure yang diikuti oleh proses pendinginan yang buruk pada tubes (Roumeau, 2010).

Konsekuensi yang mungkin terjadi sebagai akibat gagalnya outlet pigtail tubes di antaranya adalah vapor cloud karena dispersi gas, dan vapor cloud explosion (VCE). Vapor cloud explosion (VCE) merupakan ledakan yang sangat berbahaya dan merusak. Terjadi ketika sejumlah besar flammable vapor terlepas dan terdispersi membentuk kumpulan awan uap yang selanjutnya terpantik dan menimbulkan ledakan (Crowl dan Louvar, 2002). Dampak yang ditimbulkan oleh vapor cloud explosion terutama berasal dari overpressure yang dihasilkan dan berpotensi merusak alat proses maupun bangunan yang ada di sekitarnya. Oleh karena itu perlu dilakukan analisis terhadap konsekuensi yang terjadi supaya dapat diketahui seberapa besar dampak yang ditimbulkan.

Penelitian ini bertujuan untuk membuat model dispersi gas dan vapor cloud explosion yang timbul akibat dari kebocoran outlet pigtail tube. Model yang dibuat diharapkan dapat memberikan gambaran besarnya dampak yang dihasilkan vapor cloud explosion terhadap peralatan proses maupun bangunan yang ada di sekitar. 


\section{Metode Penelitian}

\subsection{Bahan Penelitian}

Penelitian ini dilakukan dengan mengumpulkan data-data sekunder yang tersaji pada Tabel 1 dan Tabel 2.

Tabel 1. Komposisi gas masuk outlet pigtail tubes

\begin{tabular}{lc}
\hline \multicolumn{1}{c}{ Komponen } & Fraksi Mol \\
\hline Metana & 0,0471 \\
Karbon dioksida & 0,0642 \\
Karbon monoksida & 0,0480 \\
Hidrogen & 0,4335 \\
Steam & 0,3970 \\
\hline Sumber: Data Pabrik Pupuk X di Jawa Barat tahun 2017
\end{tabular}

Tabel 2. Parameter proses yang digunakan

\begin{tabular}{lr}
\hline \multicolumn{1}{c}{ Parameter } & \multicolumn{1}{c}{ Nilai } \\
\hline Diameter lubang kebocoran & 1,5 inchi \\
Suhu lingkungan* & $28^{0} \mathrm{C}$ \\
Kecepatan angin* & $5,812 \mathrm{~m} / \mathrm{s}$ \\
Kelembapan udara* & $61,5 \%$ \\
Berat jenis gas & $7,097 \mathrm{~kg} / \mathrm{m}^{3}$ \\
Berat jenis udara & $1,175 \mathrm{~kg} / \mathrm{m}^{3}$ \\
Konstanta percepatan gravitasi & $9,8 \mathrm{~m} / \mathrm{s}^{2}$ \\
\hline
\end{tabular}

Sumber: www.golfweather.com

\subsection{Cara Penelitian}

Model dispersi gas yang digunakan dalam penelitian ini adalah model dense gas dispersion untuk continuous release. Persamaan perhitungan yang digunakan berdasarkan pada standar yang dikeluarkan oleh The Netherlands Organization of Applied Scientific Research (TNO, 2005). Perhitungan dimulai dengan menghitung koreksi gravitasi dan kecepatan keluar gas dari lubang kebocoran menggunakan Persamaan (2) sampai dengan Persamaan (4). Persamaan kecepatan keluar gas menggunakan Persamaan untuk choked flow. Perhitungan kecepatan gas keluar menggunakan asumsi diameter lubang kebocoran adalah diameter outlet pigtail tubes atau diameter maksimum lubang kebocoran dengan pertimbangan dapat memberikan efek yang terburuk dari keluarnya gas. Hasil perhitungan dari Persamaan (2) dan Persamaan (4) digunakan untuk menghitung rasio dari dispersi gas (Persamaan (5)) yang akan digunakan dalam pembacaan grafik Britter and McQuaid (Gambar $1)$.

$$
g_{o}=g \frac{\left(\rho_{g}-\rho_{\text {udara }}\right)}{\rho_{\text {udara }}}
$$

$$
\dot{\mathrm{m}}_{\text {choked }}=C_{d} A P_{1} \sqrt{\frac{k g_{c} M}{R_{g} T_{1}}\left(\frac{2}{\gamma+1}\right)^{\left.\frac{\gamma+1}{\gamma-1}\right)}}
$$

Kecepatan gas keluar akan digunakan untuk menentukan kecepatan volumetrik gas keluar $\left(\mathrm{v}_{\mathrm{o}}\right)$

$$
v_{o}=\frac{\dot{\mathrm{m}}_{\text {choked }}}{\rho_{g}}
$$

Rasio dari dispersi gas dihitung dengan menggunakan nilai yang diperoleh dari perhitungan sebelumnya.

$$
\left(\frac{g_{o}^{2} v_{o}}{u_{a}^{5}}\right)^{1 / 5}
$$

Jarak dispersi gas (x) ditentukan dengan melakukan pembacaan grafik Britter and McQuaid dan menghitung dengan Persamaan (6).

$$
\frac{x}{\left(\frac{v_{o}}{u_{a}}\right)^{1 / 2}}
$$

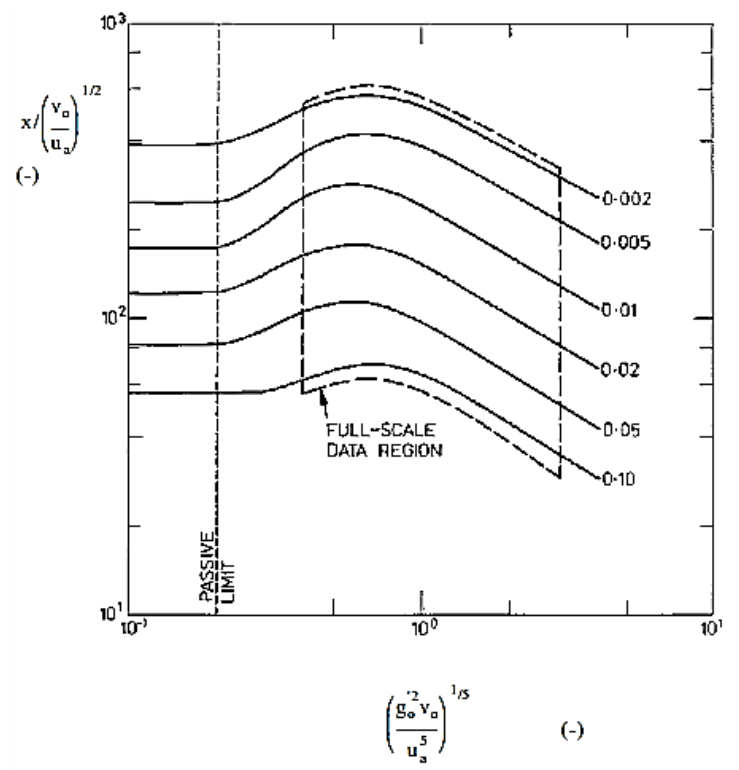

Gambar 1. Grafik Britter and McQuaid untuk jarak dispersi gas (TNO, 2005)

Upwind extension dari plume dihitung dengan menggunakan Persamaan (7), sedangkan parameter jarak $\left(\mathrm{L}_{\mathrm{b}}\right)$ dihitung dengan menggunakan Persamaan (8).

$$
\begin{aligned}
& x_{u}=b_{o}+2 L_{b} \\
& L_{b}=\frac{g_{o} v_{o}}{u_{a}^{3}}
\end{aligned}
$$

Nilai parameter jarak yang diperoleh dari 
perhitungan di atas akan digunakan untuk menghitung lebar pada Persamaan (9) dan tinggi vapor cloud yang terbentuk dari dispersi gas pada Persamaan (10).

$$
\begin{aligned}
& b(x)=2 b_{o}+8 L_{b}+2,5 L_{b}^{1 / 3} x^{2 / 3} \\
& b_{z}(x)=\frac{v_{o}}{2 u_{a} b(x)}
\end{aligned}
$$

Kecepatan volumetrik gas keluar dari lubang kebocoran dan rasio konsentrasi yang diperoleh dari grafik Britter and McQuaid akan digunakan untuk menghitung volume vapor cloud $\left(V_{c}\right)$ pada Persamaan (11). Volume vapor cloud $\left(V_{c}\right)$ yang diperoleh akan digunakan untuk menghitung energi yang dihasilkan dari vapor cloud explosion $\left(\mathrm{E}_{\mathrm{c}}\right.$ ) pada Persamaan (12).

$$
\begin{aligned}
V_{c} & =\frac{v_{o} R_{d}}{\left(C_{\text {mean }} / C_{o}\right)} \\
E_{c} & =V_{c} \Delta H_{c} 1000 \rho_{g} C_{t}
\end{aligned}
$$

Efek yang ditimbulkan dari vapor cloud explosion adalah overpressure yang mana untuk menentukan nilainya diperlukan perhitungan scaled distance $\left(r^{\prime}\right)$ dengan menggunakan Persamaan (13).

$$
r^{\prime}=\frac{x}{\left(E_{c} P_{a}\right)^{1 / 3}}
$$

Scaled distance digunakan untuk menentukan nilai scaled overpressure $\left(P_{s}{ }^{\prime}\right)$ melalui pembacaan grafik pada Gambar 2 dan scaled positive phase duration melalui pembacaan grafik pada Gambar 3. Nilai yang diperoleh kemudian digunakan untuk menghitung side blast-on overpressure $\left(\mathrm{P}_{\mathrm{s}}\right)$, positive phase duration $\left(t_{p}\right)$ dan positive impulse $\left(i_{s}\right)$ pada Persamaan (14) sampai dengan Persamaan (16).

$$
\begin{aligned}
& P_{s}=P_{s}{ }^{\prime} P_{a} \\
& t_{p}=t_{p}{ }^{\prime} \frac{\left(\frac{E_{c}}{P a}\right)^{1 / 3}}{a_{a}} \\
& i_{s}=\frac{1}{2} P_{s} t_{p}
\end{aligned}
$$

Ledakan menghasilkan gelombang overpressure yang merambat melalui tanah. Overpressure tersebut dapat menimbulkan kerusakan apabila bertemu dengan hambatan. Hambatan pada area pabrik dapat berupa bangunan maupun peralatan proses. Data mengenai kerusakan yang terjadi pada instalasi di industri sangat terbatas sehingga untuk menghitung efek dari overpressure digunakan pendekatan bangunan. Perhitungan efek overpressure pada bangunan menggunakan standar The Netherland Organization of Applied Scientific Research atau TNO yang telah diakui secara internasional (TNO, 1992). Efek overpressure berdasarkan standar TNO dibagi menjadi tiga kriteria yaitu minor damage, major damage, dan collapse. Minor damage merupakan kerusakan yang meliputi pecahnya kaca jendela, bergesernya pintu dan kerangka jendela dari tempat semula dan rusaknya sebagian atap bangunan. Major damage meliputi kerusakan seperti pada minor damage ditambah dengan retaknya dinding bangunan dan robohnya sebagian dinding bangunan. Sedangkan kriteria yang terakhir yaitu collapse merupakan kerusakan yang menyeluruh pada bangunan yang mana bangunan tersebut roboh. Ketiga kriteria dari efek overpressure dapat dihitung dengan menggunakan Persamaan (17) sampai dengan Persamaan (19).

$$
\begin{aligned}
& P_{\text {minor }}=5-0,26 \ln \left(\left(\frac{4600}{P_{S}}\right)^{3,9}+\left(\frac{110}{I_{s}}\right)^{5}\right) \\
& P_{\text {major }}=5-0,26 \ln \left(\left(\frac{17500}{P_{S}}\right)^{8,4}+\left(\frac{290}{I_{s}}\right)^{9,3}\right) \\
& P_{\text {collapse }}=5-0,22 \ln \left(\left(\frac{40000}{P_{S}}\right)^{7,4}+\left(\frac{460}{I_{S}}\right)^{11,3}\right)
\end{aligned}
$$

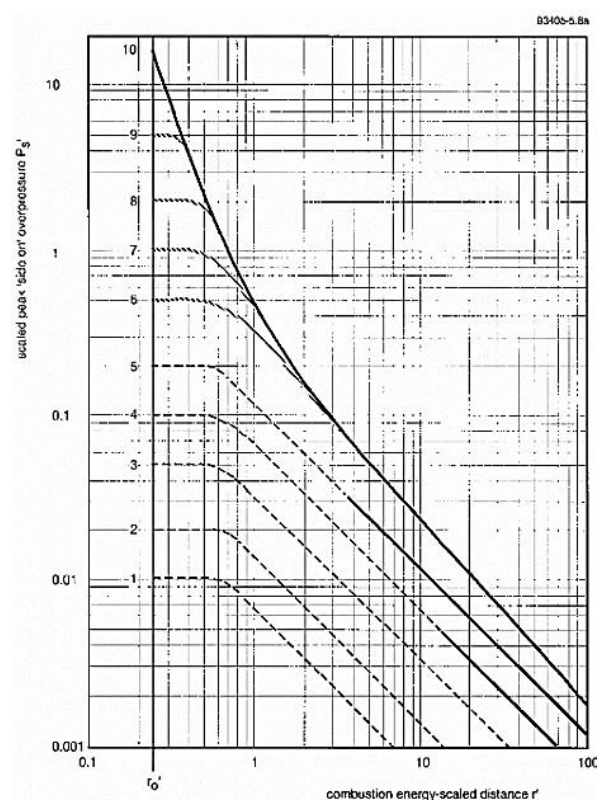

Gambar 2. Grafik multi-energy method untuk scaled overpressure (TNO, 2005) 


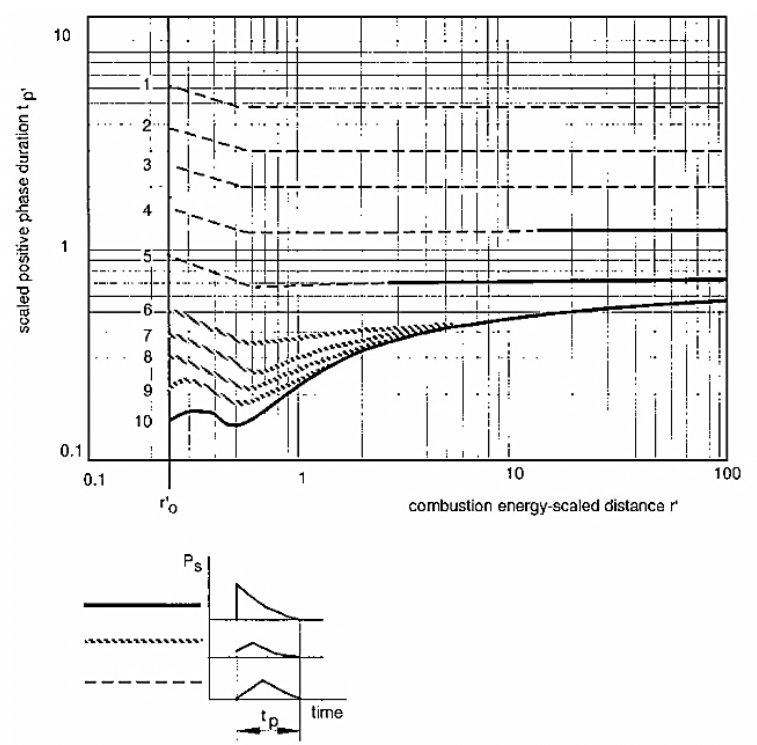

Gambar 3. Grafik multi-energy method untuk positive phase duration (TNO, 2005)

\section{Hasil dan Pembahasan}

Pemodelan dispersi gas dilakukan pada kebocoran sebuah outlet pigtail tubes dengan mengasumsikan bahwa besar lubang kebocoran sama dengan diameter outlet pigtail tube yaitu 1,5 inchi. Hasil perhitungan untuk model dispersi gas ditunjukkan oleh Gambar 4, Gambar 5, Gambar 6, dan Gambar 7.

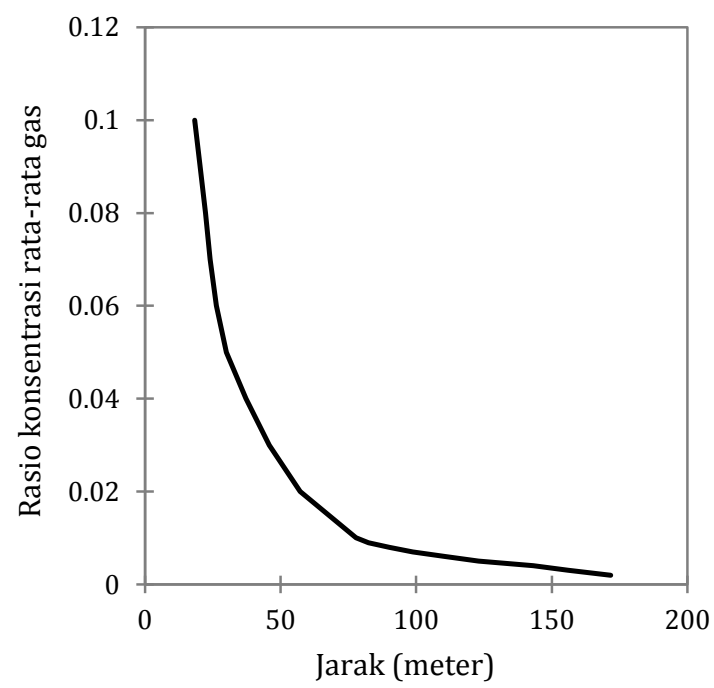

Gambar 4. Grafik hubungan rasio konsentrasi rat-rata gas terdispersi dengan jarak

Berdasarkan Gambar 4, rasio konsentrasi ratarata $\left(C_{\text {mean }} / C_{o}\right)$ tertinggi yaitu 0,1 berada pada jarak 18,3 meter sedangkan konsentrasi terendah 0,002 pada jarak 171,7 meter. Penurunan rasio konsetrasi sangat dipengaruhi oleh kecepatan angin, sehingga semakin cepat angin yang berhembus, maka penurunan kosentrasi rata-rata gas di udara semakin cepat.

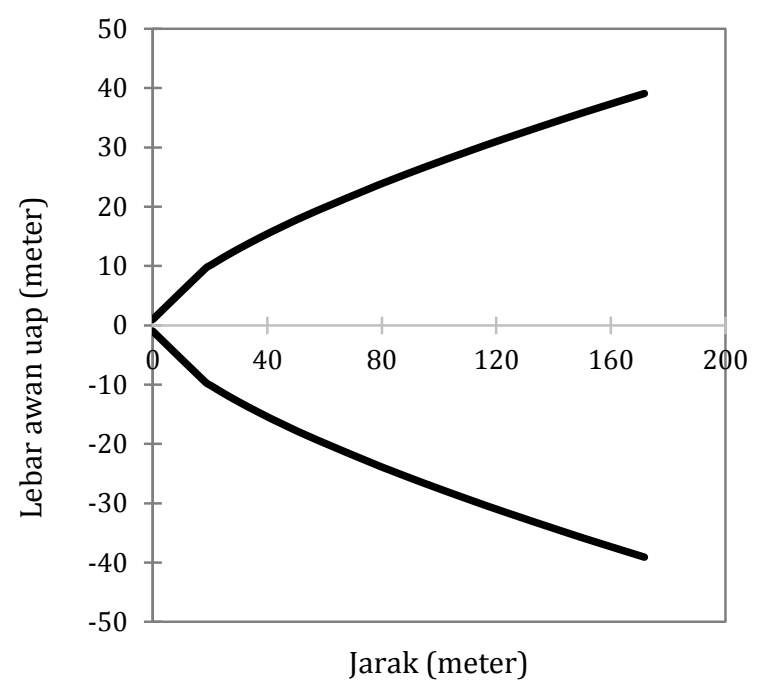

Gambar 5. Grafik hubungan lebar awan uap terdispersi dengan jarak

Berdasarkan Gambar 5, pada jarak 171,7 meter, lebar awan uap cukup besar yaitu 39,8 meter. Pendistribusian konsentrasi gas dalam udara sangat dipengaruhi oleh kecepatan massa keluar gas dan juga kecepatan angin. Kecepatan massa keluar gas sangat dipengaruhi oleh besar lubang kebocoran dan tekanan keluar gas. Oleh karena itu ketika tekanan keluar gas besar atau diameter lubang kebocoran lebih besar sedangkan kecepatan angin rendah, maka kemungkinan pembentukan awan uap dengan tingkat rasio konsentrasi yang tinggi akan lebih cepat. Hal tersebut meningkatkan tingkat kefatalan dari ledakan awan uap dan tingkat resikonya.

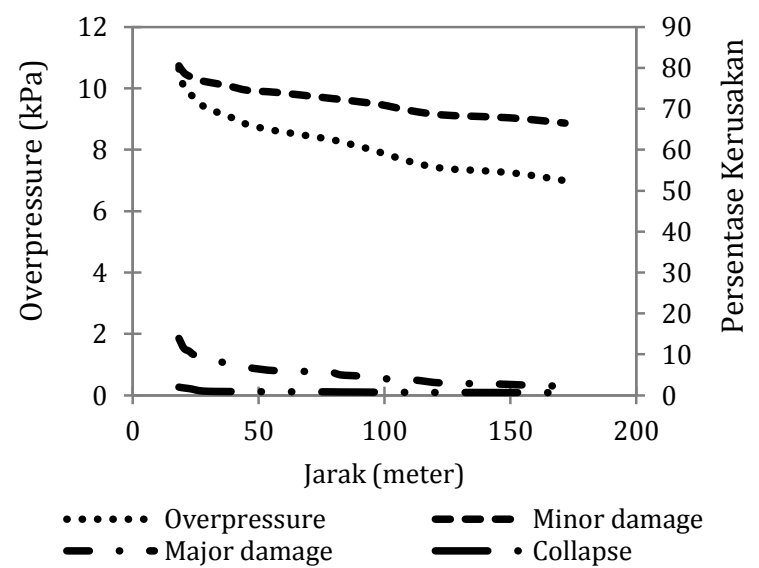

Gambar 6 Grafik hubungan antara overpressure, persentase kerusakan, dan jarak 


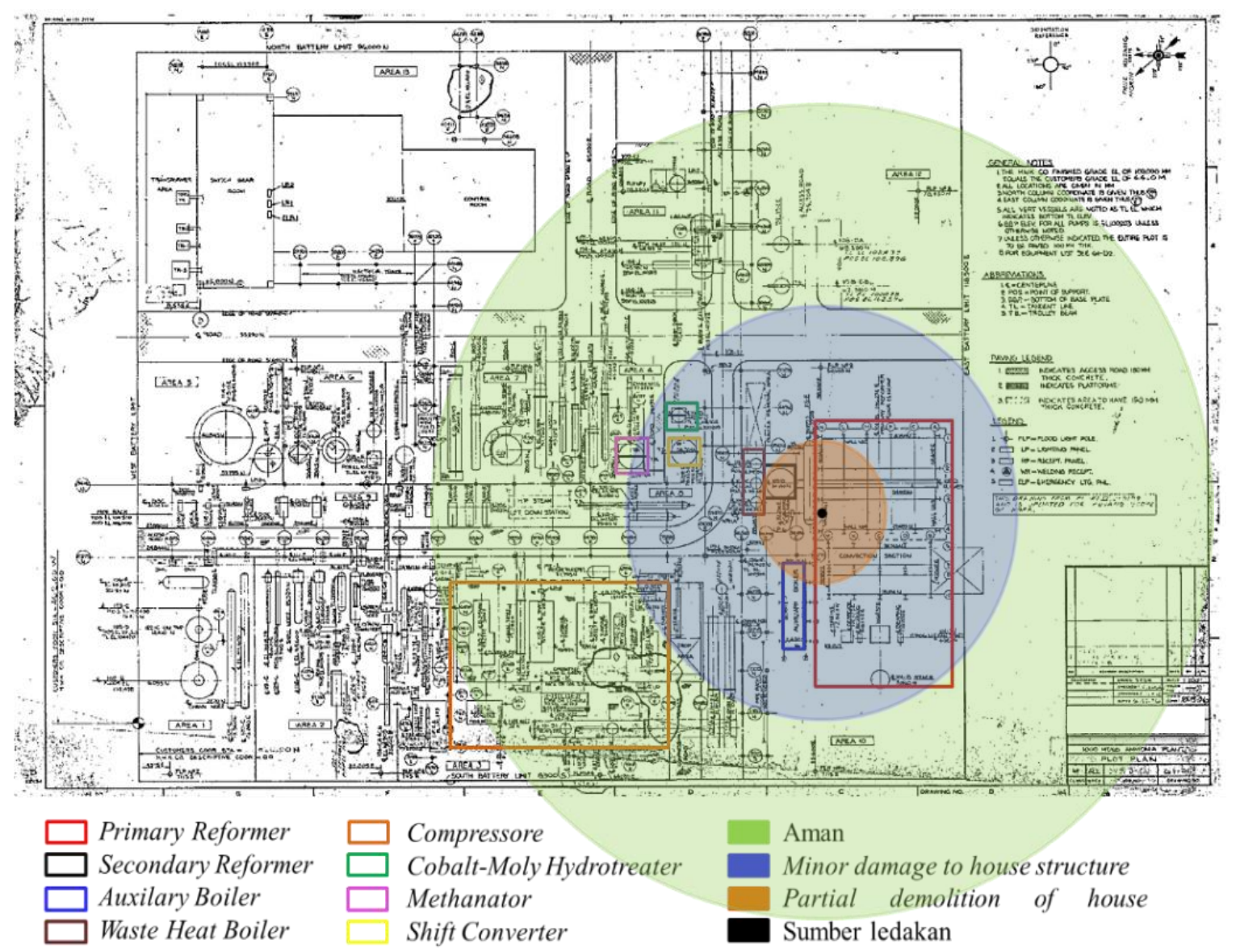

Gambar 7. Jangkauan overpressure pada area pengolahan amonia

Berdasarkan Gambar 6, energi ledakan terbesar terjadi pada jarak 18,3 meter yaitu sebesar $138 \times 10^{5} \mathrm{~kJ}$ yang memberikan overpressure sebesar $10,64 \mathrm{kPa}$. Kondisi ini dapat mengakibatkan $80,5 \%$ minor damage pada bangunan seperti rusaknya jendela, terlepasnya pintu, kerusakan pada atap, dan lainnya. Sedangkan kemungkinan untuk major damage seperti retak dan robohnya dinding bangunan adalah sekitar 13,9\%. Kerusakan yang ditimbulkan dari ledakan awan uap tidak terlalu besar. Hal ini dimungkinkan karena ukuran lubang kebocoran yang kecil sehingga konsentrasi flammable gas yang keluar tidak terlalu besar dan juga lebar awan uap yang terbentuk pada jarak tersebut tidak terlalu besar.

Berdasarkan Gambar 7 warna oranye merupakan daerah dengan overpressure 10,64 $\mathrm{kPa}$. Daerah yang tercakup dalam zona tersebut terdiri atas sebagian besar radiant section dan sebagian kecil convection section dari primary reformer, sebagian kecil secondary reformer dan auxiliary boiler. Efek yang ditimbulkan dari overpressure akan mengganggu kerja peralatan proses tersebut, namun tidak sampai menimbulkan kerusakan. Hal ini dikarenakan outlet pigtail tubes yang bocor berada di luar dinding radiant section bagian bawah. Oleh karena itu, kerusakan lebih banyak terjadi pada beberapa pipa proses yang berada di sekitar area radiant section

. Meskipun efek yang ditimbulkan oleh overpressure tidak sampai membahayakan manusia, tetapi rusaknya beberapa pipa proses dapat berujung pada shutdown pabrik. Hal tersebut menimbulkan kerugian yang cukup besar secara financial yaitu dari biaya shutdown dan perbaikan yang harus ditanggung oleh perusahaan. 
4. Kesimpulan

Kesimpulan yang dapat diambil dari penelitian ini adalah:

1. Dispersi gas dari kebocoran outlet pigtail tube dipengaruhi oleh kecepatan gas keluar dan kecepatan angin dengan rasio konsentrasi gasudara tertinggi 0,1 berada pada jarak 18,3 meter dari sumber kebocoran. Salah satu faktor yang mempengaruhi kecepatan gas keluar di samping tekanan gas keluar adalah diameter lubang kebocoran. Diameter lubang yang digunakan adalah diameter maksimum yang dapat terbentuk sebesar 1,5 inchi dan memberikan jumlah gas terdispersi yang terbesar.

2. Vapor cloud explosion yang memberikan efek terbesar berada pada jarak 18,3 meter dengan overpressure sebesar 10,64 kPa. Dampak yang ditimbulkan antara lain 80,5\% minor damage pada bangunan seperti rusaknya jendela, terlepasnya pintu, kerusakan pada atap, dan lainnya. Selain itu juga major damage seperti retak dan robohnya dinding bangunan yang berkisar 13,9\%. Selain itu gelombang overpressure yang ditimbulkan juga merusak beberapa pipa proses yang berada di sekitar area radiant section dari primary reformer yang dapat berujung pada shutdown pabrik.

\section{Daftar Notasi}

$$
\begin{aligned}
& g_{o} \quad=\text { koreksi kecepatan gravitasi, } \mathrm{m} / \mathrm{detik}^{2} \\
& g=\text { kecepatan gravitasi, } \mathrm{m} / \mathrm{detik}^{2} \\
& \rho_{g} \quad=\text { berat jenis gas, } \mathrm{kg} / \mathrm{m}^{3} \\
& \rho_{\text {udara }}=\text { berat jenis udara, } \mathrm{kg} / \mathrm{m}^{3} \\
& \dot{m}_{\text {choked }}=\text { kecepatan gas keluar, } \mathrm{kg} / \text { detik } \\
& C_{d}=\text { koefisien discharge, asumsi sama } \\
& \text { dengan pipa pecah }\left(C_{d}=1\right) \\
& A \quad=\text { luas lubang keluaran, } \mathrm{m}^{2} \\
& g_{c} \quad=\text { konstanta gravitasi, } \mathrm{kg} /\left(\mathrm{N} . \mathrm{s}^{2}\right) \\
& R_{g} \quad=\text { kostanta gas, Joule/(kgmol.K) } \\
& T_{1} \quad=\text { suhu upstream, } \mathrm{K} \\
& u_{a} \quad=\text { kecepatan angin, } \mathrm{m} / \text { detik } \\
& x_{u}=\text { upwind extension, meter } \\
& L_{b} \quad=\text { parameter, meter } \\
& b(x) \quad=\text { lebar awan uap fungsi jarak, meter } \\
& b_{o} \quad=\text { radius sumber, meter }
\end{aligned}
$$

$b_{z}(x)=$ tinggi awan uap fungsi jarak, meter

$V_{c} \quad=$ volume awan uap pada waktu dispersi tertentu, $\mathrm{m}^{3}$

$R_{d} \quad=$ lama gas keluar, detik

$E_{c} \quad=$ energi yang dihasilkan dari ledakan awan uap, Joule

$r^{\prime}=$ scaled distance

$P_{a} \quad=$ tekanan lingkungan, Pascal

$P_{s} \quad=$ side-on blast overpressure, Pascal

$t_{p} \quad=$ positive phase duration, detik

$a_{a} \quad=$ ambient speed sound, $\mathrm{m} / \mathrm{detik}$

$i_{s} \quad=$ positive impulse, Pa.detik

\section{Daftar Pustaka}

Barnett, D., Price, J., 2013, Reformer Furnace Outlet Systems: Design Considerations, Emergency Repair, and Enganced Reliability, BD Energy System, Texas.

Crowl, D.A., Louvar, J.F., 2002, Chemical Process Safety Fundamentals with Applications, $2^{\text {nd }}$ ed, Prentice Hall PTR, New Jersey.

Http://www.golfweather.com/indonesia/padanggolf-pupuk-kujang-cikampek/139024 (diakses 17 Januari 2018).

Kodali, P., Richert, J. P., 2003, Failure Mechanisms of Alloy $800 \mathrm{H}$ in Steam Reformer Furnace Pigtails, Corrosion 2003, NACE International, California.

Kusumaningtyas, L., 2010, Laporan Kerja Praktek PT Pupuk Kujang Cikampek (Persero), Jurusan Teknik Kimia, Fakultas Teknik, Universitas Gadjah Mada, Yogyakarta.

Pandey, K. K., Mistry, S., Chaklader, S. D., Gayen, R., 2017, Liquid Metal Embrittlement in Outlet Pigtails of Reformer of Hydrogen Generation Unit in Digboi Refinery, NigisCorcon, Mumbai.

Process Engineer, 2017, Data Pabrik Pupuk X di Jawa Barat, PT Pupuk X, Jawa Barat.

Roumeau, X., 2010, High Temperature Cracking of $800 \mathrm{Ht}$ Pigtails in A Hydrogen Unit, Corrosion 2010, NACE International, Texas

The Netherland Organization of Applied Scientific Research (TNO), 1992, Green Book-Methods for The Determination of 
Possible Damage: to People and Objects Resulting from Release of Hazardous

Materials, $1^{\text {st }}$ ed, Gevaarlijke Stoffen, Netherland.

The Netherland Organization of Applied Scientific Research (TNO), 2005, Yellow Book-Method for The Calculation of Physical Effects: Due to Release of Hazardous Materials (Liquid and Gases), $3^{\text {rd }}$ ed, Gevaarlijke Stoffen, Netherland. 